\title{
The role of forest plantations in the world's future timber supply ${ }^{1}$
}

\author{
by Roger A. Sedjo ${ }^{2}$
}

The nature of society's wood supply is changing. Traditionally, industrial wood has been harvested from natural forests created by nature. In the recent past, however, this situation has been changing. Planted forests have become common in some regions, e.g., much of Europe, over the past 200 years. Recently, since about 1960, intensively managed forest plantations have become increasingly common in a number of regions, including North America, Latin America, Oceania and parts of Asia. This paper explores some of the forces driving plantation forestry and some of the impacts. The experience of the U.S. is given as a type of "case study" of the types of changes that have occurred, and then a broader global discussion is undertaken. The effects of policy, technology and public attitudes on forestry are examined, both as they have influenced the past and as they are likely to impact forestry in the future.

Key words: plantations, intensive management, forest policy, technology, public attitudes

La nature de l'approvisionnement en bois est changeante. Traditionnellement, le bois industriel a été récolté dans des forêts naturelles créées par la nature. Dans un récent passé, toutefois, cette situation a été changée. Les plantations sont devenues plus communes dans certaines régions, p.ex., la majeure partie de l'Europe, au cours des 200 dernières années. Plus récemment, depuis environ 1960, les plantations aménagées intensivement sont devenues de plus en plus communes dans plusieurs régions, dont l'Amérique du Nord, l'Amérique Latine, l'Océanie et certaines parties de l'Asie. Cet article explore quelques-unes des forces sous-jacentes aux plantations et certains de leurs impacts. L'expérience américaine est présentée sous forme d' « étude de cas » des types de changements qui sont survenus, et par la suite une discussion plus générale est amorcée. Les effets des politiques, de la technologie et des attitudes du public en foresterie sont étudiés, autant parce qu'ils ont influencé le passé qu'ils sont en mesure d'avoir un impact sur la foresterie dans le futur.

Mots-clés : plantations, aménagement intensif, politiques forestières, technologie, attitudes du public.

\section{Background}

The success of modern forests, and especially high yield planted forests, has changed the nature of timber supply concerns and indeed changed dramatically the nature of the debate and even our perceptions of the types of uses to which forests can be put. An important example is found in the experience of the U.S.

The US National Forest System (NFS) had its origins at the end of the nineteenth century, when a permanent forest reserve was created. The system was created for two purposes: to secure favourable conditions of water flows, and to furnish a continuous supply of timber for the use and necessities of the people of the United States. The rationale for the creation of a reserve to furnish timber was concern that the private timber industry was short-sighted and rapacious. The industry was said to be driven by short-term profitability considerations and so, it was believed that the modus operandi was one of cut-andrun. The NFS was created to be the nation's insurance policy to ensure that there would be an adequate timber supply in the U.S.'s future.

It is noteworthy that today, one century later, the prevailing pressure on the National Forest System is the wish to set the forest aside as a biodiversity reserve. Concerns about the national forests as a supplier of timber and as an insurance policy to protect the society against the failures of the private timber industry have all but been forgotten.

Who would have thought it? How could this have occurred? It is the productivity of the private sector that makes it feasible to even consider eliminating timber harvests from the NFS. Today, the private timber industry provides almost $95 \%$ of the

${ }^{1}$ Presented to the 21 st Session of the International Poplar Commission, September 24-28, 2000, Vancouver, Washington, USA

${ }^{2}$ Senior Fellow and Director of the Forest Economics and Policy Program, Resources for the Future, Washington, D.C. industrial wood produced in the U.S. and the U.S. provides almost $30 \%$ of the world's industrial wood production.

More generally, the forest industry has a fascinating history of anticipating future timber requirements. The US industry realized that, although the huge supplies of old growth that were available on both private lands and in the national forests would

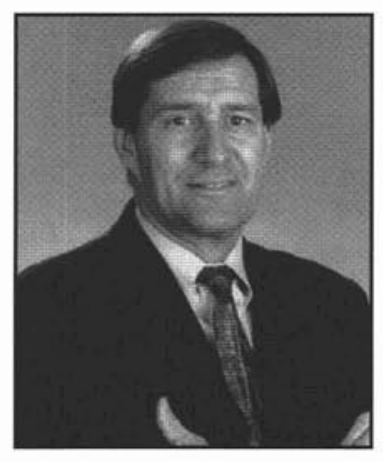
extend well out into the future, the old growth would not last forever. The timber industry also recognized that its continued existence as an industry, and as individual companies, was dependent upon maintaining a secure source of resources into the future. Finally, there was the recognition that Canada would be a major supplier of wood into the indefinite future.

In the 1930s, forest firms began seriously experimenting with reforestation and tree planting and the first commercial tree farms in the U.S. were established in the early 1940s. For the industry, planting had begun in earnest in the late 1950s and by the 1980 s over 800000 ha of new industrial forest were being planted in the U.S. each year, approximately five million seedlings per day. This level of planting has continued to this day.

Additionally, over the past several decades a host of research was undertaken on planting, spacing, thinning and other productivity-increasing activities. Tree-breeding programs were established and today it might be said that the industry is in its third generation of tree breeding.

Although many have argued that intensively managed forestry affords little or no protection to primary forests, the experience from the US National Forest System suggests that high productivity can indeed reduce the need to rely on 
natural forests for industrial wood. In the end, it has been the innovations in forestry and the remarkable increases in the productivity of the industry that allowed this society the luxury of dismissing the NFS as the nation's critical wood supply source. Without the high levels of industry productivity, it would be infeasible to seriously consider devoting the NFS almost exclusively to non-timber purposes.

\section{The Transition}

The latter part of the twentieth century has seen the beginning of a powerful transition that has been taking place in forestry and the production of wood for industry. This transition has yet to run its course. Humans had earlier made a similar transition in agriculture, over thousands of years, from foraging and hunting to planting and herding and finally to modern cropping and livestock raising.

Some elements in the transition of forestry are presented in Table 1. Wild forests were supplemented by planted forests as early as $100 \mathrm{BC}$, with some evidence that management was practised perhaps even a millennium or two earlier. By 1800 , planted forests were common in Europe, and Japan undertook tree planting in that period also. The first industrial tree planting began in the US in the early 1940s, and some earlier commercial tree planting occurred elsewhere, e.g., New Zealand in the early 1900s. However, it was not until about 1960 that intensively managed industrial plantation forests began in earnest. By the 1970 s, tree breeding was being undertaken and by 1990 , cloning had begun to arrive.

Thus, it was not until the latter half of the twentieth century that forestry was earnestly making the transition from a primitive gathering of the forest bounty, created solely by nature (old-growth harvesting), to the development of the science of tree growing (silviculture). Tree growing provided a process whereby commercial wood could become a crop, as in agriculture, to be planted, tended and harvested (Sedjo 1999a).

Tree growing allowed for a choice of location and species, as well as the opportunity to provide superior stock with desired traits. Under this regime, trees could be grown much faster and possess the traits desired by society.

Furthermore, such changes had desired environmental implications. It did not imply, as some erroneously maintain, that most natural forests were to be replaced with planted forests. Rather, the implication of the much more rapid growth associated with intensive management is that huge volumes of wood could be produced from relatively small amounts of land. This approach would provide the opportunity to use most of the natural forests for other purposes.

By the end of the century it was estimated that about onethird of global industrial wood production originated in planted forests (Table 2). Some of these were traditional in that they used indigenous species and were relatively modest in the intensity of their management. However, an increasing portion of these forests involved intensive management, often using exotic species. Furthermore, an increasing portion of the intensively managed forests now involves improved seedlings, using traditional breeding techniques. In short, forestry is adopting an agricultural cropping approach with a planting, tending and harvesting cycle.

\section{A Global Perspective}

I first became interested in plantation forestry almost 25 years ago in the late 1970s. At that time, I undertook a project to exam-
Table 1. Transitions in forest management and harvests (Sedjo 1999b).

\begin{tabular}{ll}
\hline Type & Period \\
\hline Wild forests & $10000 \mathrm{BC}$ - present \\
Managed forests & $100 \mathrm{BC}$ - present \\
Planted forests & $1800-$ present \\
Planted, intensively managed & $1960-$ present \\
Planted, superior trees, & \\
$\quad$ traditional breeding techniques & $1970-$ present \\
Cloning & $1990-$ present \\
Genetic modification & $2000 ?-$ future \\
\hline
\end{tabular}

Table 2. Global harvests by forest management condition (Sedjo 1999b)

Forest Situation Percent of Global Industrial Wood Harvest

- Old growth 22

- Second growth, minimal management 14

- Indigenous second growth, managed 30

- Industrial plantations, indigenous 24

- Industrial plantations, exotic

ine the financial potential of plantation forests in a number of regions around the world. These regions were: the Pacific Northwest, the US South, the Nordic Region, Amazonia, Central Brazil, Southern Brazil, Chile, West Africa, South Africa, Borneo, Australia and New Zealand. These regions were not picked at random but because there was some information, often sketchy, available on both growth rates and costs. This effort resulted in the publication of a book (Sedjo 1983) by Resources for the Future titled The Comparative Economics of Plantation Forestry.

Using the concept of a prototype plantation, for both pulpwood and solid wood, this study examined the potential rates of return to plantation forestry in the various regions (Table 3 ). The results suggested substantial financial potential with the possible financial rates of return running from about $6 \%$ in the Nordic Region, to over $20 \%$ in parts of South America and South Africa. Of course, I included some caveats, including noting the importance to any investor of the existence of infrastructure and political stability.

It is noteworthy that much of the world's plantation industrial wood production today is coming from some of the regions investigated twenty years ago. South America, including Brazil and Chile, are among the most successful industrial wood producers. Also, Oceania and parts of Asia are major and expanding producers. Of course, the US South continues to be a major producer of plantation industrial wood.

Over subsequent years, the investigation of plantations and timber supply has broadened. A 1990 study (Sedjo and Lyon 1990) looked at plantation forests, not in isolation, but developed a model of the world's entire wood basket, including oldgrowth, second-growth, and managed forests. The results of this study were driven by economic factors such as costs and returns, and yield functions, all of which differed by region. Projecting into the future, the study concluded that plantation forests were likely to account for an increasing portion of the world's industrial wood. This result was by virtue of the increasing costs associated with drawing wood from oldand second-growth forests, compared with the likely decrease in relative costs over time of fast-growing intensively managed plantation forests. Subsequent updates of this work (Sedjo and Lyon 1996) and dramatic updates, modifications 
Table 3. Plantation returns: representative plantations ${ }^{\mathrm{a}}$, base case: internal rate of return (assuming 1979 constant prices and costs in perpetuity) (Sedjo 1983)

\begin{tabular}{|c|c|c|c|}
\hline \multirow[b]{2}{*}{ Region/species } & \multicolumn{3}{|c|}{ Regime } \\
\hline & Pulpwood & $\begin{array}{c}\text { Integrated, with } \\
\text { standard-quality } \\
\text { sawtimber }\end{array}$ & $\begin{array}{l}\text { Integrated, with } \\
\text { lower-quality } \\
\text { Sawtimber }\end{array}$ \\
\hline \multicolumn{4}{|l|}{ North America } \\
\hline \multicolumn{4}{|l|}{ U.S. South } \\
\hline Pinus taeda, avg.-yield site & 12.02 & 12.45 & - \\
\hline Pinus taeda, high-yield site & 13.91 & 14.12 & - \\
\hline \multicolumn{4}{|l|}{ Pacific Northwest } \\
\hline Pseudotsuga menziesii, avg.-yield site & 7.11 & 7.07 & - \\
\hline Pseudotsuga menziesii, high-yield site & 8.85 & 9.62 & \\
\hline \multicolumn{4}{|l|}{ South America } \\
\hline \multicolumn{4}{|l|}{ Brazil, Amazonia } \\
\hline Pinus caribaea & 17.89 & 20.44 & 19.25 \\
\hline Gmelina spp. & 27.53 & 23.54 & - \\
\hline \multicolumn{4}{|l|}{ Brazil, Central } \\
\hline Eucalptus spp. & 20.16 & 15.54 & - \\
\hline \multicolumn{4}{|l|}{ Brazil, Southern } \\
\hline Pinus taeda & 15.57 & 17.53 & 16.79 \\
\hline \multicolumn{4}{|l|}{ Chile } \\
\hline Pinus radiata & 23.39 & 17.50 & 16.01 \\
\hline \multicolumn{4}{|l|}{ Oceania } \\
\hline $\begin{array}{l}\text { Australıa } \\
\text { Pinus radiata }\end{array}$ & Australia & 10.06 & 8.94 \\
\hline \multicolumn{4}{|l|}{ New Zealand } \\
\hline Pinus radiata & 11.90 & 13.11 & 11.13 \\
\hline \multicolumn{4}{|l|}{ Africa } \\
\hline \multicolumn{4}{|l|}{ South Africa } \\
\hline Pinus patula & 19.34 & 17.69 & 16.27 \\
\hline \multicolumn{4}{|l|}{ Gambia-Senegal } \\
\hline Gmelina spp. & 18.42 & 17.52 & - \\
\hline Eucalyptus spp. & 12.16 & 14.71 & \\
\hline \multicolumn{4}{|l|}{ Europe } \\
\hline \multicolumn{3}{|l|}{ Nordic } & \\
\hline $\begin{array}{l}\text { Picea abies } \\
\text { Asia }\end{array}$ & \multicolumn{3}{|c|}{ Asia } \\
\hline $\begin{array}{l}\text { Asla } \\
\text { Borneo }\end{array}$ & & & \\
\hline Pinus caribaea & 12.94 & 14.73 & 13.61 \\
\hline
\end{tabular}

${ }^{a}$ Three alternative management regimes were assumed. The "low-quality" regime assumed that plantation sawtimber would sell at a discount.

and expansions of the model (Sohngen et al. 1999) only tended to reinforce our earlier conclusion that the role of planted forests in global timber supply will continue to increase through time.

\section{Other Factors, Political and Economic, Encouraging Forest Plantations}

There are also other factors that tend to support the conclusion of continued increases in planted forests. A recent paper (Sedjo and Botkin 1997) argued that plantation forests have not only a cost advantage over traditional forestry, but also an ecological advantage. In essence, the argument is that it is "greener" to intensively manage a small area for industrial wood than to harvest old growth or to extensively manage, and impact, large areas. The paper estimated that all of the world's current and likely future wood requirements could be produced on a land area that would be about 5-10\% of the world's existing forested area. This estimate includes a certain fraction of total production coming from non-plantation forests that provide wood with certain desired characteristics not readily available from plantations.

Additionally, this paper examined the potential of non-wood fibre sources, including annual cropping of plants such as hemp, bagasse, etc. These types of fibre sources have a number of economic and ecological problems. A major economic problem is that there is a specific peak harvesting period. Subsequently, the crop must be stored and preserved until it is to be processed. Both of these functions incur cost. By contrast, timber can generally be harvested throughout the year, or at least through a much larger portion of the year than an annual crop, and it can be stored for a longer period of time. Thus, labour and capital equipment can be used, essentially, year round. Furthermore, wood tends to resist deterioration better than non-woody plants. From an environmental perspective it is difficult to see how an annual crop, planted and harvested every year, can be more benign to the environment than a tree crop planted in year one and harvested in, e.g., year 20. The annual crop generates 40 disturbances of the land over a 20-year period compared with two disturbances with the tree crop.

There are other forces that encourage the movement from natural to planted forests. These forces are found in the continuing pressure by the environmental movement for the protection and set-aside of more native and natural forest areas. As more forested areas are set aside for protection and preservation, less of this type of forest is available for logging and the costs of obtaining wood from these sources rise. There are 
hosts of examples from the U.S. and elsewhere. An important example is that of the national forests in the U.S., which I touched on above. In 1988 timber harvests from US national forests were about 0.028 billion $\mathrm{m}^{3}$. This level was gradually reduced through the 1990 s to about 0.07 billion $\mathrm{m}^{3}$ in 1999 . It is clear that for some areas the target would be essentially a zero harvest. Protected areas are being established in many parts of the globe. The Nordic countries, for example, now have protected areas as a result of revisions in their national forest policies that occurred in the mid-1990s (Sedjo et al. 1997).

Additionally, new forest practices acts and codes are also increasing the costs of harvest. Canadian timber harvests have not been exempt from some of the same types of pressures. In addition to the establishment of areas protected from harvests, a number of new forest practices codes have been put into effect in the various provinces. Although these codes may apply to planted forests as well as natural forests, the cost increases, which are often found in roading standards, riparian zones and the like, can be expected to be greatest for natural forests. For example, the recent revised British Columbia forest practices code has been estimated to increase the costs of BC timber harvests by at least 15\% (Haley 1996). In the Nordic countries also, new forest policies are estimated to raise production and harvesting costs substantially.

\section{Other Innovations}

The above discussion argues that the costs of harvesting natural and native forests are rising, due to the effects of both availability and restrictive practices. By contrast, the costs of intensively managed plantations tend to be falling due to new techniques, improved plants and the like. Here is another example of declining wood costs from plantations. A recent paper (Yin 2000) examines the growth, yield and economics of changing forestry in Georgia. It finds the following:

"Using data for loblolly pine from Georgia's Piedmont, we find that, while the transition from natural to artificial regeneration leads to increased and better distributed stems, the control of competing vegetation (in second generation plantations) results in a dramatic boost to the growth rate from previous to current generation plantations."

It concludes that while:

“... previous generation plantation on cut-over lands only slightly improved the profitability and cost competitiveness, compared to natural stands, ... current generation plantations can boost production, ... thereby reducing costs ... and dramatically increasing profitability."

These findings indicate that rather mundane and undramatic changes in management activities, e.g., controlling competing vegetation, can dramatically increase productivity and profitability of plantations. The author argues that current practices allow for dramatic improvements using current technology.

\section{Plantations Worldwide}

What then is the status of planted forests worldwide? This is not an easy question to address since data of this type are not regularly documented. Nevertheless, based on a number

\begin{tabular}{lcc}
\hline \multicolumn{3}{l}{ Table 4. Industrial plantation area: total and fast-growing (Bazett 1993) } \\
\hline Region & $\begin{array}{c}\text { Total } \\
\text { (million ha) }\end{array}$ & $\begin{array}{c}\text { Fast-growing } \\
\text { (million ha) }\end{array}$ \\
\hline North America & 12.5 & $12.5^{\mathrm{a}}$ \\
Latin American & 6.4 & 6.4 \\
Asia & 39.8 & 0.7 \\
Africa & 2.5 & 2.5 \\
Europe & 19.0 & 6.4 \\
CIS & 16.9 & 0.0 \\
Oceania & 2.2 & 2.2 \\
Total & $\mathbf{9 9 . 3}$ & $\mathbf{2 5 . 3}$ \\
\hline
\end{tabular}

ancludes US South as fast-growing

of studies during the 1990s, we can get a general idea of the situation (see Sedjo 1999a). Looking at Table 4 on fastgrowing and other industrial plantations, for example, we see that fast-growing plantations dominate in Latin America and the US (south) as well as being significant in Europe and Oceania.

\section{The Promise and Problems of Breeding and Biotechnology in Forestry}

Planted forests offer the opportunity for the introduction of improved stock, including that which is improved or genetically altered. One point is clear. Plantations may persist without biotechnology, but biotechnology cannot reasonably be introduced into forestry production without forest plantations. Indeed, without the opportunity to plant and cultivate the plantings, much of the research in forestry, both traditional and that involving genetic alterations, would find no applications.

Table 5 provides estimates of the gains to various traditional breeding approaches. Obviously, substantial gains can be achieved.

As is well known, there is opposition to the application of genetic modification in agriculture and, recently, forestry. Nevertheless, if forestry proceeds to adopt genetically modified approaches, it seems to be agreed that, for the foreseeable future in forestry, traditional breeding and genetic modification will proceed hand in hand. Traditional breeding is used to provide a superior seedling, and genetic modification is introduced to provide an additional advantage or set of advantages.

In many respects, biotechnology in forestry is retracing its earlier path in agriculture. Perhaps the genetic modification that is nearest to commercial is that of a herbicide-resistant gene, very much like that being applied on a wide scale to soybean and other crops. Other gene alterations that are fairly well developed include the Bt gene, which would be applied to pests.

A recent investigation to estimate the potential economic benefits that could be generated through the introduction of genetic innovation to forestry has found these benefits to be substantial (Sedjo 1999b). The advantages of the new technology can be viewed in either of two essentially equivalent ways. Innovation can increase the yield, or the output per unit cost, thereby reducing the unit costs. Or technology can allow for the same production at reduced costs, again reducing the unit cost.

Lower costs are likely to have two effects. In the near-term, profitability per unit will rise. Over the longer period, the increased profitability is likely to increase production, thereby lower- 
Table 5. Gains from various traditional breeding approaches: loblolly pine (Source: Westvaco Corporation)

\begin{tabular}{lc}
\hline Technique & Effect: increase in yields \\
\hline Orchard Mix, open pollination, first & \\
$\quad$ Generation & $8 \%$ \\
Family Block, best mothers & $11 \%$ \\
Mass Pollination (control for both male and & \\
$\quad$ female) & $21 \%$ \\
\hline
\end{tabular}

\section{Table 6. Priority traits of interest in forestry}

Herbicide tolerance

Flowering control

Fibre/lignin modification

Insect tolerance

Disease tolerance

Wood density

Girowth

ఫิtem straightness

Sutrient uptake

Qold, wet, drought tolerance

Jing prices and eroding some of the increased profitability. The Rear-term effect increases firm profitability while the longer刃erm effect provides the consumer with lower prices.

$\forall$ Table 6 lists a number of traits that are of interest to forestry and that are likely to be amenable to biotechnology. Doreliminary research has suggested that, as with agriculture, The returns to these activities can be substantial (Sedjo 1999b). ar example, experts estimate that herbicide resistance would Jegluce the costs of plantation establishment by an average of allout $\$ 85 /$ ha for fast-growing softwoods and an average of \$190/ha for fast-growing hardwoods (Context Consulting In . In the U.S. this could generate a cost savings estimat20 to $\$ 150$ million annually. Worldwide, the estimated potentiis savings from the introduction of the herbicide-resistant gene Fuld be as high as $\$ 975$ million annually.

\section{1. \\ Auditing and Certification}

Another force working against natural forests is likely to be ertification. As practised, certification appears to be most contraining for harvests in natural forests. The concern appears fo be largely that the nature of the natural forest is not excesछively modified, clear-cuts are avoided, and regeneration is assured and largely "natural" in character. By contrast, although \$lantations are frowned upon by some certifiers, they are 8fften allowed. Some have claimed that where planted forests gre established on bare ground, a common situation, there is Fittle concern for the past history of the site, since no prior forest existed (in recent years). Hence, some have claimed, the establishment of a certified plantation in South America is essentially the same as the establishment of a high-yielding industrial plantation, since there are no constraints based upon an existing or earlier forest condition.

This issue promises to become more charged should genetically modified seedlings come into use. As it now stands, some certifiers, e.g., the Forest Stewardship Council, reject planted forests that involve genetically altered organisms, and will not certify forests using this technology. Of course, with many auditing and certifying organizations it remains to be determined what will be the long-term role of biotechnology in forestry (Sedjo et al. 1997).

\section{Summary and Conclusions}

This paper has shown that forest plantations are already playing a major role in the production of industrial wood and has argued that this role is likely to increase substantially in future years. Intensively managed forest plantations have both economic and environmental advantages. As costs rise for harvests in old growth and natural forests due to prohibitions and more stringent logging practices, the relative costs of plantations are declining. These declines reflect both improved knowledge of appropriate silvicultural practices and improved stock due to traditional breeding techniques. Additionally, plantation location in regions favourable to tree growth results in increased yields and reduced costs. Furthermore, many current certification schemes appear to favour plantations. Finally, the application of genetic modification to trees offers the promise of additional advantages to planted forests in the future.

\section{References}

Bazett, M. 1993. Industrial Wood. Shell/World Wildlife Fund, Tree Plantation Review Study No. 3. World Wildlife Fund (United Kingdom) Panda House, Weyside Park, Godalming, Surrey.

Context Consulting. n.d. West Des Moines, IA 50266.

Haley, D. 1996. Paying the Piper: The Cost of the British Columbia Forest Practices Code. Paper presented at the conference, Working with the British Columbia Forest Practices Code, and Insight Information Inc. Sponsored by the Globe and Mail, Vancouver, British Columbia, April 15-17.

Sedjo, R.A. 1983. The Comparative Economics of Plantation Forests. Resources for the Future, Washington, DC.

Sedjo, R.A. 1999a. The potential of high-yield plantation forestry for meeting timber needs. New Forests 17: 339-359.

Sedjo, R.A. 1999b. Biotechnology and planted forests: assessment of potential and possibilities. Discussion Paper 00-07. Resources for the Future, Washington, DC.

Sedjo, R.A. and D. Botkin. 1997. Using Forest Plantations to Spare Natural Forests. Environment 39(10): 15-20, 30.

Sedjo, R.A., A. Goetzl and S. Moffat. 1997. Sustainability of Temperate Forests. Resources for the Future, Washington, DC.

Sedjo, R.A. and K.S. Lyon. 1990. The Long-Term Adequacy of World Timber Supply. Resources for the Future, Washington, DC.

Sedjo, R.A. and K.S. Lyon. 1996. Timber supply model 96: a global timber supply model with a pulpwood component. Discussion Paper 96-15. Resources for the Future, Washington, DC.

Sohngen, B., R. Mendelsohn and R. Sedjo. 1999. Forest management, conservation, and global timber markets. American Journal of Agricultural Economics 81(1).

Yin, R. 2000. Comparing the performance of loblolly pine management regimes: the case of Georgia's Piedmont. Unpublished paper. Warnell School of Forest Resources, University of Georgia, Athens, GA. 